INOBIS: Jurnal Inovasi Bisnis dan Manajemen Indonesia

Volume 1, Nomor 3, Juni 2018

Maria Endang Jamu

\title{
Analisis Faktor-Faktor yang Mempengaruhi Minat Berwirausaha Mahasiswa
}

(Studi Kasus Pada Mahasiswa Manajemen Universitas Flores)

\author{
Maria Endang Jamu \\ Fakultas Ekonomi ,Universitas Flores - Ende \\ endangjamu2@gmail.com
}

\begin{abstract}
Abstrak
Penelitian ini bertujuan untuk menganalisis faktor-faktor yang mempengaruhi minat berwirausaha mahasiswa jurusan manajemen, universitas flores. Penelitian ini menggunakan metode deskriptif kuantitatif untuk menguji hipotesa antar variabel penelitian.Variabel yang digunakan dalam penelitian ini adalah faktor personal, sociological serta environmental dan pengaruhnya terhadap minat berwirausaha mahasiswa. Populasi penelitian ini adalah mahasiswa prodi manajemen angkatan 2016 dengan sampel penelitian sebanyak 60 mahasiswa yang sudah lulus mata kuliah kewirausahaan. Teknik penentuan sampel yang digunakan adalah purposive sampling.Teknik analisis data menggunakan SEM (Structural Equation Model) dengan Smart PLS 3. Berdasarkan hasil analisis data dan pembahasan diketahui bahwa minat mahasiswa untuk berwirausaha dilihat dari faktor personal, dan environmental dinilai tinggi, sedangkan berdasarkan faktor sociological diketahui tidak memiliki pengaruh yang positif atau kurang signifikan terhadap minat berwirausaha mahasiswa.
\end{abstract}

Kata kunci: faktor personal, sociological, environmental dan minat berwirausaha mahasiswa

\section{Pendahuluan}

Badan Pusat Statistik Indonesia memperkirakan bahwa Indonesia merupakan negara nomor empat terbesar di dunia dalam hal jumlah penduduk. Besarnya jumlah penduduk merupakan salah satu keuntungan jika ditinjau dari segi pasar untuk menopang perkembangan industri di dalam negeri dan dapat menjadi kekuatan yang besar, jika sumber daya manusianya dikembangkan secara tepat. Disisi lain dengan jumlah penduduk yang begitu besar menyebabkan pemerintah dan masyarakat Indonesia menghadapi berbagai permasalahan sosial ekonomi yang sangat signifikan seperti pengangguran, kemiskinan, dan kesenjangan lainnya.

Pertumbuhan penduduk yang terus bertambah setiap tahunnya akan menambah jumlah tenaga kerja sehingga jumlah lapangan pekerjaan yang harus disediakan harus terus ditingkatkan. Masalah utama dalam dunia ketenagakerjaan yang dihadapi saat ini adalah tingginya tingkat pengangguran karena pertambahan jumlah tenaga kerja yang tidak sebandingdengan jumlah ketersediaan lapangan kerja.

Suatu hal yang tak dapat dipungkiri bahwa Indonesia menghadapi masalah keterbatasan kesempatan kerja bagi para lulusan perguruan tinggi dengan semakin meningkatnya jumlah pengangguran intelektual belakangan ini.Data dari Badan Pusat Statistik Indonesia menyatakan bahwa jumlah pengangguran paling tinggi berasal dari lulusan lulusan perguruan tinggi (Setiadi, 2008). Kondisi yang dihadapi akan semakin diperburuk dengan situasi persaingan global yaitu Masyarakat Ekonomi ASEAN (MEA) yang menuntut para lulusan 
INOBIS: Jurnal Inovasi Bisnis dan Manajemen Indonesia

Volume 1, Nomor 3, Juni 2018

\section{Maria Endang Jamu}

perguruan tinggi Indonesia untuk dapat bersaing secara bebas dengan lulusan dari perguruan tinggi asing. Banyaknya angka pengangguran disebabkan oleh minimnya jiwa kewirausahaan masyarakat.Kecenderungan menunjukkan bahwa semakin tinggi tingkat pendidikan semakin besar keinginan untuk mendapatkan pekerjaan yang aman.Salah satu alternatif untuk memecahkan masalah pengangguran adalah dengan memberdayakan masyarakat dan kelompok terdidik melalui program kewirausahaan yang diharapkan mampu berkontribusi dalam penyerapan tenaga kerja sehingga mengurangi pengangguran dan beban negara (Adnyana dan Purnami, 2016).

Ada tiga strategi utama yang digalakkan oleh pemerintah dalam melakukan penyuluhan tentang kewirausahaan bagi masyarakat Indonesia, yaitu pemberdayaan, kewirausahaan, inovasidan teknologi.Strategi yang digalakkan ini mempunyai sasaran yang luas.Pada tingkatan dunia pendidikan, hal ini mulai diperkenalkan dari tingkatan sekolah menengah, hingga ke perguruan tinggi untuk memberikan motivasi dan pengetahuan tentang pentingnya berwirausaha. Hal ini bertujuan agar mempersiapkan para lulusan yang nantinya akan terjun dalam masyarakat, memiliki ilmu dan mental menjadi seorang entrepreneur, sehingga, jumlah pengangguran di Indonesia dapat berkurang.

Saat ini perguruan tinggi berperan penting untuk menanamkan sikap, mental kewirausahaan terhadap para mahasiswanya melalui pendidikan entrepreneurship yang dimasukan ke dalam kurikulum pendidikan yang wajib ditempuh.Peranan perguruan tinggi dalam mengembangkan minat berwirausaha mahasiswa dengan menggali faktor-faktor yang berpengaruh pada perilaku berwirausaha menjadi hal yang sangat penting. Minat berwirausaha akan menjadikan seseorang untuk lebih giat mencari dan memanfaatkan peluang usaha dengan mengoptimalkan potensi yang dimiliki. Minat sangat dibutuhkan bagi mahasiswa yang berwirausaha agar mampu mengidentifikasi peluang usaha, kemudian mendayagunakan peluang usaha untuk menciptakan peluang kerja baru.Melalui pendidikan entrepreneurship diharapkan para mahasiswa memiliki kepribadian, pemahaman dan kemampuan dibidang kewirausahaan sehingga dapat meningkatkan kualitas hidup dirinya sendiri dan berkontribusi secara baik bagi masyarakat.

Stewart dkk(1998) menyatakan bahwa tumbuhnya minat berwirausaha dipengaruhi oleh berbagai faktor, yaitu; faktor internal dan faktor eksternal.Faktor internal yang berasal dari dalam diri wirausahawan dapat berupa sifat-sifat personal, sikap, kemauan dan kemampuan individu yang dapat memberi kekuatan individu untuk berwirausaha.Faktor eksternal berasal dari luar diri pelaku entrepreneur yang dapat berupa unsur dari lingkungan sekitar seperti lingkungan keluarga, lingkungan dunia usaha, lingkungan fisik, lingkungan sosial ekonomi dan lain-lain.

Suryana (2008) juga menyatakan bahwa faktor yang berasal dari lingkungan diantaranya adalah model peran, peluang, aktivitas, selain itu dipengaruhi juga oleh para pesaing, sumber daya, dan kebijakan pemerintah.

David C.Mclelland dalam Suryana (2008) dan Rose (2006) menyatakan bahwa kewirausahaan ditentukan oleh motif berprestasi, optimisme, sikap nilai, dan status kewirausahaan atau keberhasilan. Pengaruh pendidikan kewirausahaan selama ini telah dipertimbangkan sebagai salah satu faktor penting untuk menumbuh kembangkan hasrat, jiwa dan perilaku berwirausaha di kalangan generasi muda.Selanjutnya diperlukan adanya pemahaman tentang bagaimana mengembangkan dan mendorong lahirnya wirausaha muda yang potensial kedepannya.

Berdasarkan uraian diatas, maka peneliti merasa perlu untuk melakukan penelitian dengan tujuan menganalisis faktor-faktor yang mempengaruhi minat berwirausaha mahasiswa (Studi Kasus pada Mahasiswa Jurusan Manajemen Universitas Flores-Ende). 
INOBIS: Jurnal Inovasi Bisnis dan Manajemen Indonesia

Volume 1, Nomor 3, Juni 2018

Maria Endang Jamu

\section{Landasan Teori}

\subsection{Minat}

Menurut Crow dan Crow (dalam Killis, 1988)Minat adalah kecenderungan dalam diri individu untuk tertarik pada sesuatu objek atau menyenangi sesuatu objek.Selanjutnya Killis juga mengemukakan bahwa minat adalah pendorong yang menyebabkan seseorang memberi perhatian terhadap orang, sesuatu, aktivitas-aktivitas tertentu.Crow dan Crow (dalam Djaali 2006:12) mengatakan bahwa minat berhubungan dengan gaya gerak yang mendorong seseorang untuk menghadapi atau berurusan dengan orang, benda, kegiatan, pengalaman yang diransang oleh kegiatan itu sendiri.

Djamarah (2008:132) berpendapat bahwa minat adalah kecenderungan yang menetap untuk memperhatikan dan mengenang beberapa aktivitas. Seseorang yang berminat terhadap aktivitas akan memperhatikan aktivitas itu secara konsisten dengan rasa senang.

Menurut Charles AT (1989)minat dideskripsikan sebagai berikut: Pada awalnya sebelum terlibat di dalam suatu aktivitas, seseorang mempunyai perhatian, menimbulkan keinginan untuk terlibat, oleh karena itu minat kemudian mulai memberikan daya tarik atau ada pengalaman yang menyenangkan dengan hal-hal tersebut. Seseorang yang berminat terhadap suatu aktivitas akan memperhatikan aktivitas itu secara konsisten dengan rasa senang dikarenakan hal tersebut datang dari dalam diri seseorang yang didasarkan rasa suka dan tidak adanya paksaan dari pihak luar. Dengan kata lain, minat adalah suatu rasa lebih suka dan rasa keterikatan pada suatu hal atau aktivitas, tanpa ada yang memaksa.

Menurut Slameto (2003) minat adalah penerimaan akan suatu hubungan antara diri sendiri dengan sesuatu diluar diri. Semakin kuat atau dekat hubungan tersebut, semakin besar minatnya.

Dari beberapa definisi minat yang dikemukakan di atas dapat disimpulkan bahwa minat adalah kecenderungan individu untuk memusatkan perhatian dan rasa ketertarikan terhadap suatu objek atau situasi tertentu secara konsisten.

Menurut Alma (2007) menyatakan terdapat 3 faktor kritis yang berperan dalam minat berwirausaha yaitu:

1). Personal; yaitu menyangkut aspek-aspek kepribadian seseorang (perasaan dan emosi, persepsi, motivasi, pembelajaran (sikap), pendapatan, motivasi, cita-cita, dan harga diri). David Mcceland dalam Alma (2007:13) dalam bukunya The achieving society menyatakan bahwa seorang wirausaha adalah seseorang yang yang memiliki keinginan berprestasi yang sangat tinggi dibandingkan orang yang tidak berwirausaha.

2). Sociological; yaitu menyangkut masalah hubungan dengan keluarga dan hubungan sosial lainya. Alma (2007:7) menyatakan bahwa hubungan sosial dapat berbentuk "role model" yang dapat berpengaruh terhadap minat berwirausaha seseorang. Yang dapat dijadikan sebagai role model biasanya seperti orang tua, saudara, keluarga, teman-teman, pasangan, atau pengusaha sukses yang diidolakanya.

3). Environmental; yaitu menyangkut hubungan dengan lingkungan. Suryana (2008:63) menyatakan faktor yang berasal dari lingkungan di antaranya adalah model peran, peluang, aktivitas, selain itu di pengaruhi juga oleh pesaing, sumber daya, dan kebijakan pemerintah. 
INOBIS: Jurnal Inovasi Bisnis dan Manajemen Indonesia

Volume 1, Nomor 3, Juni 2018

Maria Endang Jamu

\subsection{Kewirausahaan}

Menurut Stewart,dkk (1998)kewirausahaan adalah usaha untuk menciptakan nilai melalui pengenalan kesempatan bisnis, manajemen pengambilan risiko yang tepat, dan melalui keterampilan komunikasi dan manajemen untuk memobilisasi manusia, uang, dan bahan-bahan baku atau sumber daya lain yang diperlukan untuk menghasilkan proyek supaya terlaksana dengan baik.

Hisrich dkk, (2008) mendefinisikan kewirausahaan sebagai proses menciptakan sesuatu yang baru dengan nilai, dengan menghitung waktu dan usaha, dan mempertimbangkan resiko biaya, fisik, dan sosial. Dengan tujuan mendapatkan keuntungan, kepuasan, dan kebebasan.

Dari kedua definisi tersebut di atas ditekankan bahwa kegiatan kewirausahaan berkaitan dengan peluang bisnis, penciptaan nilai, pengambilan resiko, dan penggunaan sumber daya.

Menurut Sunarya dkk,(2011)istilah kewirausahaan merupakan terjemahan dari kata entrepreneurship yang diartikan sebagai the backbone economy, yaitu syarat pusat perekonomian atau sebagai tailbone economy, yaitu pengendalian perekonomian suatu bangsa.Kata kewirausahaan berasal dari kata wirausaha.Kata wirausaha berasal dari kata wira artinya berani, utama, mulia.Usaha berarti kegiatan bisnis komersil maupun non komersil. Jadi kewirausahaan diartikan secara harfiah sebagai hal-hal yang menyangkut keberanian seseorang untuk melakukan kegiatan bisnis maupun non bisnis secara mandiri

Hisrich dkk(2008), mendeskripsikan pemahaman wirausaha atau entrepreneur sebagai individu yang mengenali peluang dimana orang lain justru melihat kekacauan dan kebingungan. Kewirausahaan adalah simbol dari kegigihan dan prestasi bisnis. Wirausaha akan terus menjadi kontributor yang penting untuk pertumbuhan ekonomi melalui kepemimpinan, manajemen, inovasi, penelitian, dan pengembangan efektivitas, penciptaan lapangan kerja, daya saing, produktivitas dan pembentukan industri baru.Definisi entrepreneur (wirausaha) adalah orang yang berani mengambil resiko mengambil resiko artinya bermental mandiri dan berani memulai usaha, tanpa diliputi rasa takut atau cemas sekalipun dalam kondisi tidak pasti peluang akan dengan mudah dimanfaatkan seorang entrepreneur untuk membuat usaha baru dengan potensi profit yang besar. Tidak hanya peluang dalam kondisi positif (baik), tetapi juga dalam kondisi buruk.Entrepreneur dapat dengan mudah menganalisa permintaan barang atau jasa yang dibutuhkan masyarakat untuk membuka usaha dalam berbagai kesempatan.

Schumpeter dalam Alma (2009) mengartikan wirausaha sebagai seorang yang mendobrak sistem ekonomi yang ada dengan memperkenalkan produk dan jasa yang baru, dengan menciptakan bentuk organisasi baru atau mengolah bahan baku. Schumpeter juga menambahkan, bahwa wirausahawan melihat adanya peluang, lalu menciptakan sebuah organisasi untuk memanfaatkan peluang tersebut.

\subsection{Tujuan Penelitian}

Menganalisis Faktor-faktor yang Mempengaruhi Minat Berwirausaha Mahasiswa Jurusan Manajemen Uniflor- Ende. 
INOBIS: Jurnal Inovasi Bisnis dan Manajemen Indonesia

Volume 1, Nomor 3, Juni 2018

Maria Endang Jamu

\subsection{Hipotesis Penelitian}

Berdasarkan latar belakang dan landasan teori di atas, maka Hipotesis dari penelitian ini adalah; faktor personal, sociological dan environmental berpengaruh positif terhadap minat berwirausaha mahasiswa.

\subsection{Kerangka Penelitian}

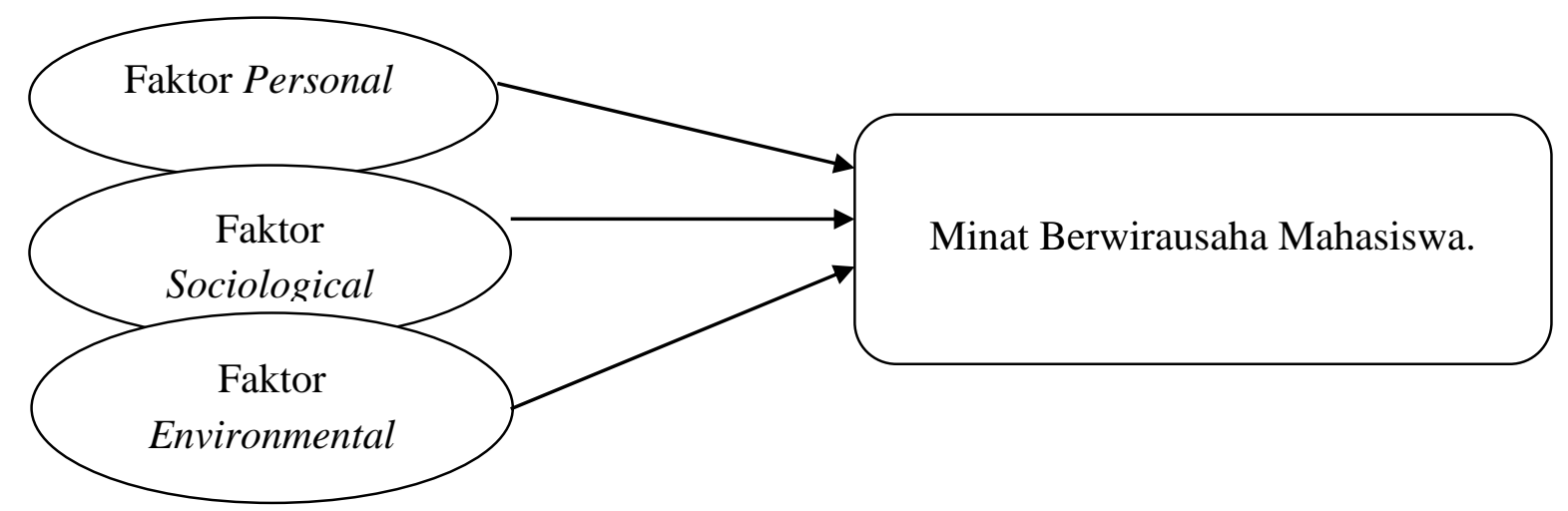

Gambar 1. Kerangka Model Penelitian

\section{Metode Penelitian}

Penelitian ini menggunakan data kuantitatif untuk menguji hipotesa antar variabel penelitian.Variabel yang digunakan dalam penelitian ini adalah faktor personal, sociologicalsertaenvironmental dan pengaruhnya terhadap minat berwirausaha mahasiswa.Penelitian ini dilakukan terhadap mahasiswa jurusan manajemen Uniflor, angkatan 2016 yang sudah lulus mata kuliah kewirausahaan. Teknik pengambilan sampel dalam penelitian ini adalah purposive sampling, yaitu metode pengambilan sampel yang dilakukan berdasarkan pertimbangan peneliti yang dipilih secara cermat dan memiliki kriteria tertentu sesuai kebutuhan penelitian, serta mudah dijangkau oleh peneliti.Dalam metode ini, cara pemilihan sampel dilakukan secara acak (random). Populasi penelitian ini adalah sebanyak 70 orang mahasiswa dan untuk menentukan ukuran sampel minimum menggunakan rumus Solvin dengan batas toleransi kesalahan5\%(Sevilla dkk, 2007), sehingga jumlah sampel yang digunakan dalam penelitian ini adalah 60 orang. Ukuran sampel minimum digunakan karena beberapa dari populasi belum lulus atau belum mengambil mata kuliah kewirausahaan.

Instrumen yang digunakan dalam penelitian ini adalah kuesioner, yang disebarkan kepadamahasiswa jurusan manajemen Uniflor, angkatan 2016yang sudah lulus mata kuliah kewirausahaan.Semua pernyataan dalam kuesioner ini, disediakan lima alternatif jawaban dengan menggunakan skala Likert yaitu dari gradasi tertinggi sampai terendah, $5=$ sangat setuju, $4=$ setuju, $3=$ netral, $2=$ tidak setuju, $1=$ sangat tidak setuju.

Pernyataan kuesioner penelitian sebagai berikut:

Personal (X1)

1). Saya mempunyai keinginan untuk meningkatkan kualitas hidup diri sendiri

2). Saya memiliki pemikiran optimis dan kemampuan untuk berwirausaha

3). Saya senang untuk berwira usaha dan menyukai tantangan baru 
INOBIS: Jurnal Inovasi Bisnis dan Manajemen Indonesia

Volume 1, Nomor 3, Juni 2018

Maria Endang Jamu

4). Saya mempunyai keinginan untuk memiliki pendapatan sendiri

5). Saya memiliki kemampuan untuk melihat peluang yang baru

6). Saya memiliki kemampuan untuk menciptakan peluang yang baru

Sociological (X2)

1). Saya berminat untuk berwirausaha setelah mengikuti mata kuliah kewirausahaan

2). Saya berminat untuk berwirausaha setelah melihat orang-orang disekitar yang sukses berwirausaha

3). Saya berminat untuk berwirausaha karena dorongan dari orang-orang terdekat saya

4). Saya berminat untuk berwirausaha karena melihat usaha yang dirintis oleh orang tua saya

5). Saya berminat untuk berwirausaha karena teman-teman disekitar saya memiliki usaha

6). Saya berminat untuk berwirausaha karena melihat usaha yang dirintis oleh keluarga besar saya

Environmental (X3)

1). Mampu mengidentifikasi, mendayagunakan peluang usaha untuk menciptakan lapangan kerja baru

2). Memiliki akses yang mudah untuk mendapatkan modal usaha

3). Mampu mencari dan memanfaatkan peluang usaha dengan mengoptimalkan potensi yang saya miliki

4). Adanya keterbatasan kesempatan kerja bagi para lulusan perguruan tinggi dengan semakin meningkatnya jumlah pengangguran intelektual belakangan ini

5). Adanya penyuluhan dari pemerintah dan pihak lainnya tentang kewirausahaan bagi masyarakat Indonesia

6). Adanya kebijakan pemerintah untuk mendorong lahirnya wirausaha muda yang potensial kedepannya.

Data penelitian dianalisis menggunakan SEM-PLS (Partial Least Squares-Stuctural Equation Modeling) dengan Smart PLS3.Analisis SEM-PLS terdiri atas dua sub model yaitu model pengukuran (measurement model) atau disebut outer model dan model stuktural (structural model) atau disebut inner model. Model pengukuran menunjukkan bagaimana variabel manifest merepresentasikan variabel laten untuk diukur, sedangkan model struktural menunjukkan kekuatan estimasi antara variabel laten atau konstruk. Ada 2 model pengukuran yang digunakan dalam analisis SEM-PLS yaitu;

A. $\quad$ Model pengukuran (Outer model)

Evaluasi model pengukuran (outer model) dalam SEM-PLS dilakukan untuk menguji validitas dan reliabilitas data penelitian.Pada uji validitas dapat dilakukan dengan melihat dua hal yaitu :

1). Validitas convergen(convergent validity).Pengukuran dapat dikategorikan memenuhi validitas convergen, apabila nilai loading indicator $>0,70$.

2). Validitas diskriminan (discriminant validity). Validitas diskriminan ditentukan dengan melihat (1) akar kuadrat average variance extracted (AVE), lebih besar daripada 
INOBIS: Jurnal Inovasi Bisnis dan Manajemen Indonesia

Volume 1, Nomor 3, Juni 2018

Maria Endang Jamu

korelasi antar konstruk. (2)loading indicator ke konstruk yang diukur lebih besar daripada loading ke konstruk lain.

Pada uji reliabilitas dapat dilihat dari dua hal sebagai berikut :

1). Cronbach alpha. Suatu item pernyataan dapat dinyatakan reliabel jika, nilai Cronbach alpha $>0,60$.

2). Composite reliability. Suatu item pernyataan dinyatakan reliabel, jika nilai Composite reliability $>0,70$.

\section{B. Model struktural (inner model)}

Evaluasi terhadap inner model dilakukan untuk melihat pengaruh antara variabel laten, serta digunakan untuk mengukur signifikansi keterdukungan hipotesis.Untuk melihat pengaruh antara variabel laten, dapat dilakukan dengan melihat besarnya nilai $\mathrm{R}^{2}$ ( $R$-square). Semakin besar nilai $\mathrm{R}^{2}$, maka semakin besar pula pengaruh langsung variabel laten eksogen terhadap variabel endogen.

Menurut Kock dalam Sholihin, (2013)signifikansi keterdukungan hipotesis dapat dilakukan dengan cara melihat model struktural yang terdiri dari hubungan yang dihipotesiskan diantara konstruk-konstruk laten dalam model penelitian. Analisis SEM-PLS, dapat memperoleh koefisien jalur (path coefficients), yang selanjutnya dapat digunakan oleh peneliti untuk menilai signifikansi statistik model penelitian dengan menguji hipotesis untuk tiap jalur hubungan. Hipotesis penelitian dapat diterima jika $P$-values $\leq 0.05$.

\section{Hasil dan Pembahasan}

\subsection{Deskripsi Para Mahasiswa}

Dari jumlah total kuesioner sebanyak 60 buah yang disebar kepada mahasiswa jurusan manajemen Uniflor, angkatan 2016 yang sudah lulus mata kuliah kewirausahaan, jumlah kuesioner yang diisi dan dikembalikan adalah sebanyak 60 kuesioner dan selanjutnya dinyatakan layak untuk dianalisis lebih lanjut.

\subsection{Hasil Penelitian}

\subsubsection{Analisis Data}

Teknik pengolahan data dengan menggunakan metode SEM berbasis Partial Least Square (PLS) memerlukan 2 tahap untuk menilai Fit Model dari sebuah model penelitian (Ghozali, 2006). Tahap-tahap tersebut adalah sebagai berikut :

\subsubsection{Menilai Outer Model atau Measurement Model}

Evaluasi model pengukuran (outer model) pada SEM-PLS perlu dilakukan dua pengujian, yaitu uji validitas dan reliabilitas.Pada uji validitas dapat dilakukan dengan melihat dua hal yaitu validitas convergen (convergent validity) dan validitas diskriminan (discriminant validity). Pengukuran dapat dikategorikan memiliki validitas convergen, apabila nilai loading indicator $>0,70$. Validitas diskriminan (discriminant validity) ditentukan dengan melihat (1).akar kuadrat average variance extracted (AVE), lebih besar dari pada 
INOBIS: Jurnal Inovasi Bisnis dan Manajemen Indonesia

Volume 1, Nomor 3, Juni 2018

Maria Endang Jamu

korelasi antar konstruk. (2). loading indicator ke konstruk yang diukur lebih besar dari pada loading ke konstruk lain. Pada uji reliabilitas dapat dinyatakan reliabel jika, nilai Cronbach alpha $>0,60$ dan nilai composite reliability $>0,70$.

Data kuesioner yang diisi oleh 60 responden yang merupakan mahasiswa jurusan manajemen Uniflor, angkatan 2016 diolah menggunakan SEM-PLS sehingga diperoleh nilai outer loading untuk setiap indikator variabel seperti pada tabel berikut.

Tabel 1.Outer Loading

\begin{tabular}{|c|c|c|c|c|}
\hline & Personal & Sociological & Environment & Minat \\
\hline P1 & 0.725 & & & \\
\hline $\mathrm{P} 2$ & 0.766 & & & \\
\hline $\mathrm{P} 3$ & 0.819 & & & \\
\hline $\mathrm{P} 4$ & 0.827 & & & \\
\hline P5 & 0.712 & & & \\
\hline $\mathrm{P} 6$ & 0.767 & & & \\
\hline S1 & & 0.731 & & \\
\hline $\mathrm{S} 2$ & & 0.795 & & \\
\hline S3 & & 0.703 & & \\
\hline S4 & & 0.757 & & \\
\hline S5 & & 0.824 & & \\
\hline S6 & & 0.775 & & \\
\hline E1 & & & 0.725 & \\
\hline E2 & & & 0.803 & \\
\hline E3 & & & 0.759 & \\
\hline E4 & & & 0.771 & \\
\hline E5 & & & 0.746 & \\
\hline E6 & & & 0.784 & \\
\hline Minat & & & & 1.000 \\
\hline
\end{tabular}

Sumber : data primer yang diolah 2018

Dari tabel 1.di atas, diketahui bahwa untuk semua indikator yang menyusun masingmasing variabel telah memenuhi syarat validitas convergen karena nilai loading factor $>0,70$.

Tabel 2. Average Variances Extracted

\begin{tabular}{|l|c|}
\hline Personal & 0.600 \\
\hline Sociological & 0.585 \\
\hline Environment & 0.585 \\
\hline Minat & 1.000 \\
\hline
\end{tabular}

Sumber : data primer yang diolah 2018

Dari tabel 2.diketahui bahwa semua indikator yang menyusun masing-masing variabel, telah memenuhi syarat validitas diskriminan karena nilai akar kuadrat average variance extracted (AVE) $>0.50$. 
INOBIS: Jurnal Inovasi Bisnis dan Manajemen Indonesia

Volume 1, Nomor 3, Juni 2018

Maria Endang Jamu

Tabel 3. Discriminant Validity

\begin{tabular}{|l|l|l|l|l|}
\hline & Personal & Sociological & Environment & Minat \\
\hline P1 & 0.752 & 0.634 & 0.584 & 0.570 \\
\hline P2 & 0.766 & 0.539 & 0.546 & 0.634 \\
\hline P3 & 0.819 & 0.543 & 0.526 & 0.694 \\
\hline P4 & 0.827 & 0.445 & 0.533 & 0.703 \\
\hline P5 & 0.712 & 0.461 & 0.471 & 0.592 \\
\hline P6 & 0.767 & 0.556 & 0.653 & 0.659 \\
\hline S1 & 0.434 & 0.731 & 0.626 & 0.431 \\
\hline S2 & 0.498 & 0.757 & 0.525 & 0.474 \\
\hline S3 & 0.588 & 0.795 & 0.582 & 0.606 \\
\hline S4 & 0.408 & 0.703 & 0.517 & 0.432 \\
\hline S5 & 0.585 & 0.824 & 0.731 & 0.583 \\
\hline S6 & 0.557 & 0.775 & 0.75 & 0.684 \\
\hline E1 & 0.492 & 0.523 & 0.725 & 0.531 \\
\hline E2 & 0.539 & 0.672 & 0.803 & 0.670 \\
\hline E3 & 0.635 & 0.635 & 0.759 & 0.588 \\
\hline E4 & 0.527 & 0.595 & 0.771 & 0.625 \\
\hline E5 & 0.521 & 0.672 & 0.746 & 0.524 \\
\hline E6 & 0.553 & 0.685 & 0.784 & 0.560 \\
\hline Minat & 0.832 & 0.718 & 0.766 & 1.000 \\
\hline
\end{tabular}

Sumber : data primer yang diolah 2018

Berdasarkan Tabel 3. di atas dapat diketahui bahwa semua indikator yang menyusun masing-masing variabel dalam penelitian ini telah memenuhi validitas diskriminan, karena nilai cross loading menunjukkan bahwa nilai korelasi konstruk dengan indikatornya lebih besar dari pada nilai korelasi dengan konstruk lainnya.

Selanjutnya adalah uji reliabilitas dapat dilakukan dengan melihat nilai dari composite reliability dan Cronbach's alphamasing-masing konstruk atau variabel:

Tabel 4. Composite Reliability

\begin{tabular}{|l|c|c|} 
& \multicolumn{1}{c|}{$\begin{array}{c}\text { Composite } \\
\text { Reliability }\end{array}$} & $\begin{array}{c}\text { Cronbach's } \\
\text { alpha }\end{array}$ \\
\hline Personal & 0.900 & 0.866 \\
\hline Sociological & 0.894 & 0.860 \\
\hline Environment & 0.894 & 0.858 \\
\hline Minat & 1.000 & 1.000 \\
\hline
\end{tabular}

Sumber : data primer yang diolah 2018

Data tabel 4.di atas menunjukkan bahwa semua variabel dinyatakan reliabel karena nilai composite reliability $>0,70$ dan nilai Cronbach's alpha $>0,60$.

\subsubsection{Model Struktural (Inner Model)}

Evaluasi inner model dilakukan untuk melihat pengaruh antara variabel laten dan juga digunakan untuk melakukan pengujian terhadap hipotesis. Pengaruh antara variabel laten 
INOBIS: Jurnal Inovasi Bisnis dan Manajemen Indonesia

Volume 1, Nomor 3, Juni 2018

Maria Endang Jamu

dapat dilihat dari nilai $R$-square. Semakin besar nilai $R$-square, maka semakin besar pengaruh variabel laten eksogen terhadap variabel laten endogenserta signifikansi dari koefisien parameter jalur struktural.

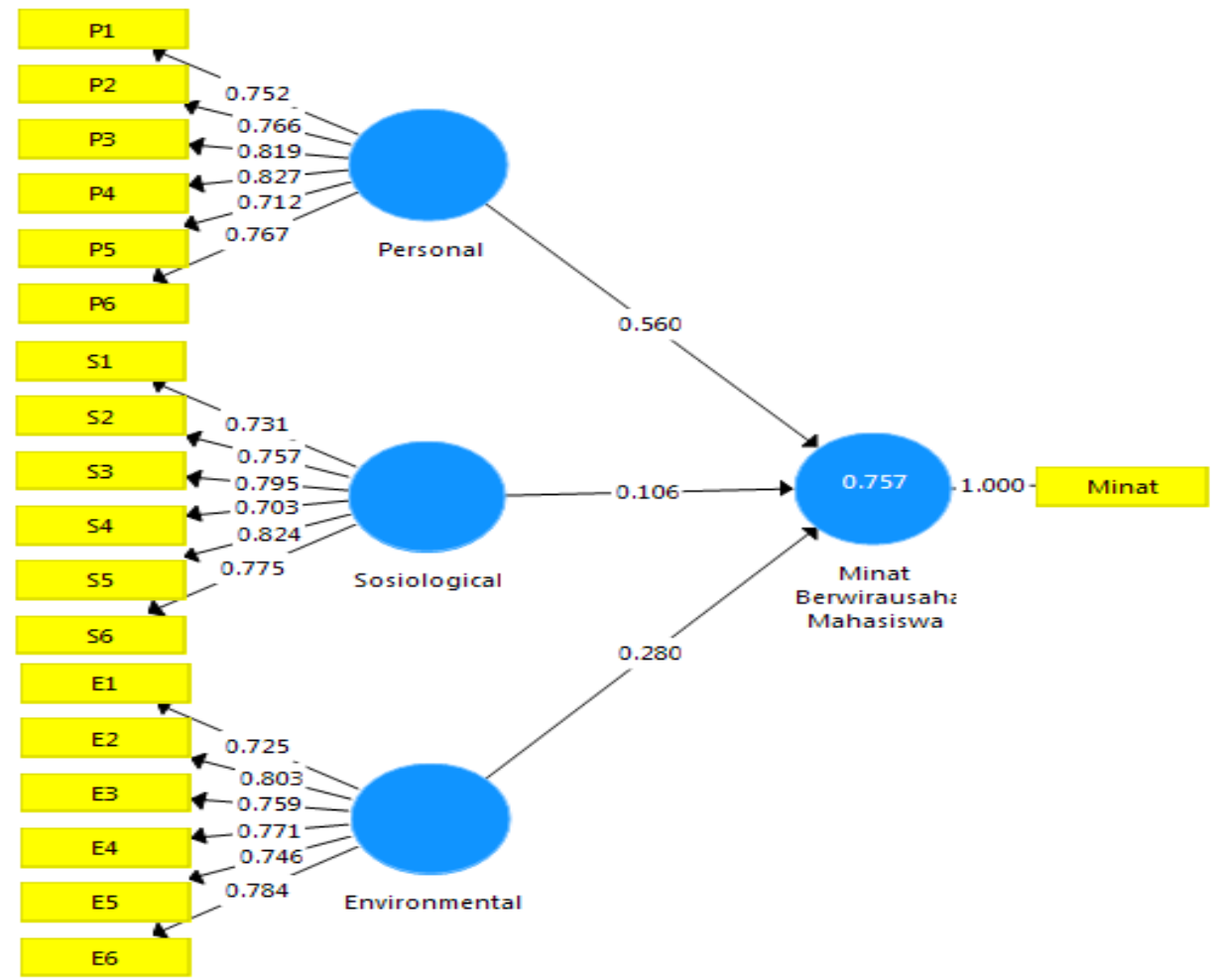

Gambar 2. Model Stuktural

Sumber : data primer yang diolah 2018

Berdasarkan pengolahan data dengan SEM-PLS 3.0 Professional, dihasilkan nilai $R$ square sebagai berikut:

Tabel 5.R-Square

\begin{tabular}{|l|c|c|}
\hline & $\begin{array}{r}\boldsymbol{R}- \\
\text { Square }\end{array}$ & $\begin{array}{c}\text { R-Square } \\
\text { Adjusted }\end{array}$ \\
\hline Minat Berwirausaha & 0.757 & 0.744 \\
\hline
\end{tabular}

Sumber : data primer yang diolah 2018

Dari tabel 5.di atas diketahui bahwa faktor-faktor yang mempengaruhi minat ; Personal, Sociological dan Environmentalmempunyai pengaruh yang signifikan terhadap minat berwirausaha mahasiswa dengan nilai $R$-square sebesar 0.757 atau $76 \%$.

\subsubsection{Pengujian Hipotesis}

Signifikansi parameter yang diestimasi memberikan informasi yang sangatberguna mengenai hubungan antara variabel-variabel penelitian. Dasar yangdigunakan dalam menguji hipotesis adalah nilai yang terdapat pada output result forinner weight. 
INOBIS: Jurnal Inovasi Bisnis dan Manajemen Indonesia

Volume 1, Nomor 3, Juni 2018

Maria Endang Jamu

Tabel 6. Result for Inner Weights

\begin{tabular}{|c|c|c|c|c|}
\hline Variabel & \begin{tabular}{l}
\multicolumn{1}{c}{ Original } \\
Sample Estimate \\
$(O)$
\end{tabular} & \begin{tabular}{lc}
\multicolumn{2}{c}{ Mean } \\
Of & Sub \\
Samples $(M)$ \\
\end{tabular} & $\begin{array}{l}\text { Standard } \\
\text { deviation } \\
(\text { STEDEV })\end{array}$ & \begin{tabular}{l}
\multicolumn{1}{c}{$T-$} \\
Statistics \\
$($ O/STERR $)$
\end{tabular} \\
\hline Personal-Minat & 0.560 & 0.571 & 0.071 & 7.915 \\
\hline Sociological - Minat & 0.106 & 0.101 & 0.082 & 1.301 \\
\hline Environment - Minat & 0.280 & 0.287 & 0.097 & 2.883 \\
\hline
\end{tabular}

Sumber : data primer yang diolah 2018

Hasil pengujian hipotesis pertama menunjukkan bahwa hubungan variabel personaldengan minat berwirausaha mahasiswa menunjukkan nilai koefisien jalur sebesar 0.560 dengan nilai $t$ sebesar 7.915 , nilai tersebut lebih besar dari t tabel $(1,670)$.Hasil ini berarti bahwa faktor personal memiliki hubungan yang positif dan signifikan terhadap minat berwirausaha mahasiswa.

Variabel sociologicaldengan minat berwirausaha mahasiswa menunjukkan nilai koefisien jalur sebesar 0.106 dengan nilai t sebesar 1.301, nilai tersebut lebih kecil dari t tabel $(1,670)$.Hasil ini berarti bahwa faktor sociological tidak memiliki hubungan yang positif atau kurang signifikan terhadap minat berwirausaha mahasiswa.

Variabel environmentdengan minat berwirausaha mahasiswa menunjukkan nilai koefisien jalur sebesar 0.280 dengan nilai t sebesar 2.883, nilai tersebut lebih besar dari t tabel $(1,670)$.Hasil ini berarti bahwa faktor environment memiliki hubungan yang positif dan signifikan terhadap minat berwirausaha mahasiswa. Dengan demikian hal ini mengindikasikan bahwa hipotesis dalam penelitian ini diterima atau didukung

\subsection{Pembahasan}

Hasil penelitian ini secara keseluruhan memberikan gambaran bahwa pada dasarnya faktor-faktor yang mempengaruhi minat, khususnya faktor personal, dan environmental menunjukkan bahwaminat untuk berwirausahapara mahasiswa, dinilai tinggi.Hal ini mengindikasikan bahwa aspek-aspek kepribadian seseorang (perasaan, emosi, persepsi, motivasi, pembelajaran (sikap), motivasi, cita-cita, dan harga diri), dan faktor environmentalyaitu menyangkut hubungan dengan lingkungan di antaranya adalah model peran, peluang, aktivitas, persaingan, sumber daya, dan kebijakan pemerintah yang mendorong tumbuhnya para entrepreneur, menjadi indikator yang mendorong keinginan para mahasiswa untuk menciptakan nilai melalui kesempatan bisnis, keterampilan serta yakin akan kemampuan dirinya untuk memobilisasi manusia, uang, dan sumber daya lain yang diperlukan untuk memiliki usaha sendiri, kebebasan dalam beraktivitas, berprestasi, optimisme, dan status kewirausahaan atau keberhasilan.

Disisi lain bahwa faktor sociological diketahui tidak memiliki pengaruh positif atau kurang signifikan terhadap minat berwirausaha mahasiswa. Hal ini mengindikasikan ada suatu kemungkinan bahwa para mahasiswa bukan atau tidak berasal dari latar belakang orang tua, saudara, keluarga, yang memiliki usaha atau lingkungan sosial pada umumnya tidak beraktivitas (profesi) sebagai wirausaha, sehingga para mahasiswa tidak memiliki "role model" atau menjadi figur yang dapat menumbuhkan minat mereka untukmenjadi entrepreneur. 
INOBIS: Jurnal Inovasi Bisnis dan Manajemen Indonesia

Volume 1, Nomor 3, Juni 2018

Maria Endang Jamu

\section{Kesimpulan dan Saran}

\subsection{Kesimpulan}

Berdasarkan hasil penelitian maka dapat disimpulkan sebagai berikut:

1. Faktor personal, dan environmental mempunyai pengaruh yang signifikan terhadap minat berwirausaha mahasiswa jurusan manajemen Uniflor, angkatan 2016. Hal ini didorong oleh keinginan untuk meningkatkan kualitas hidup diri sendiri, memiliki pemikiran optimis dan kemampuan untuk berwirausaha, senang untuk berwirausaha dan menyukai tantangan baru, keinginan untuk memiliki pendapatan sendiri, memiliki kemampuan untuk melihat dan menciptakan peluang yang baru. Disisi lain bahwa para mahasiswa memiliki kemampuan mengidentifikasi, mendayagunakan peluang usaha untuk menciptakan lapangan kerja baru, adanya akses yang mudah untuk mendapatkan modal usaha, mampu mencari dan memanfaatkan peluang usaha dengan mengoptimalkan potensi yang dimiliki, adanya keterbatasan kesempatan kerja bagi para lulusan perguruan tinggi dengan semakin meningkatnya jumlah pengangguran intelektual belakangan ini serta adanya penyuluhan dan kebijakan pemerintah untuk mendorong lahirnya wirausaha muda yang potensial kedepannya.

2. Faktor sociologicaldiketahui tidak berpengaruh secara signifikanterhadap minat berwirausaha mahasiswajurusan manajemen Uniflor, angkatan 2016. Hal ini dipengaruhi oleh faktor sosial individu mahasiswa yaitu kurang adanya dorongan dari orang-orang terdekat seperti orang tua, saudara dan keluarga untuk berwirausaha atau mereka tidak berasal dari latar belakang orang tua, saudara, keluarga, yang memiliki usaha, serta pengalaman melihat orang-orang disekitar yang gagal dalam berwirausaha.

\subsection{Saran}

1. Peranan perguruan tinggi dalam mengembangkan minat berwirausaha individu mahasiswa melalui matakuliah kewirausahaan, pemupukan jiwa kewirausahaan dengan latihan atau praktek kewirausahaan bagi mahasiswa melalui bussines planserta pemberian pemahaman tentang bagaimana mengembangkan dan mendorong lahirnya wirausaha muda yang potensial kedepannya menjadi hal yang sangat penting dan menjadi perhatian utama.

2. Peningkatan intensi berwirausaha juga dapat dikembangkan dengan kunjungan ke tempat wirausaha yang sukses atau mengadakan seminar atau pelatihan motivasi kewirausahaan agar menambah semangat mahasiswa dalam minat berwirausaha.

3. Perlu adanya dorongan dan bimbingan dari orang tua, saudara, keluarga tentang pentingnya berwirausaha.

\section{Daftar Pustaka}

Adnyana, I.G.L.A. \& Purnami, N.M. (2016). Pengaruh Pendidikan Kewirausahaan, SelfEfficacy dan Locus of Control Pada Niat Berwirausaha. E-Jurnal Manajemen Unud, 5(2), 2016.

Alma, B. 2007.Kewirausahaan.Alfabeta.Bandung.

Alma, Buchari. 2009. Kewirausahaan. Alfa Beta. Bandung.

Djaali. 2006. Psikologi Pendidikan. Jakarta : PT Bumi Aksara. 
INOBIS: Jurnal Inovasi Bisnis dan Manajemen Indonesia

Volume 1, Nomor 3, Juni 2018

Maria Endang Jamu

Djamarah, Syaiful Bahri. (2008). Psikologi Belajar.Jakarta : PT. Rineka Cipta.

Ghozali, Imam. 2006. Structural Equation Modeling, Metode Alternatif dengan Partial Least Square.Edisi 2. Badan Penerbit Universitas Diponegoro: Semarang.

Hisrich.D.Robert, Michael P.Peters dan Dean A.Shepherd. 2008. Kewirausahaan.Terjemahan Chriswan Sungkono danDiana Angelica , Jakarta Salemba Empat.

John Killis. (1988). Hubungan Minat Kerja, Motivasi Ekstrinsik dan Bimbingan dalam Pelajaran dengan Kecakapan Kerja Teknik Listrik Lulusan STM pada Industri-industri DIY.Tesis. Jakarta: Fakultas Pasca Sarjana. IKIP.Jakarta.

Kementerian Koperasi dan UMKM.http://www.depkop.go.id

Rose, R.C, Kumar, N. dan Yen, L.L. 2006. The dynamics of entrepreneurs' success factors in influencing venture growth. Journal of Asia Entrepreneurshipand Sustainability. 2, 123

Setiadi, U. (2008). Suatu Pemikiran Mengenai Pendekatan Kembali Antara Dunia Pendidikan S1 Manajemen Dengan Dunia Kerja.Prosiding Konferensi Merefleksi Domain Pendidikan Ekonomi dan Bisnis.Salatiga.

Stewart, W.H., Watson, W.E., Carland, J.C. dan Carland, J.W. 1998. A proclivity for entrepreneurship: A comparison of entrepreneurs, small business owners, and corporate managers. Journal of Business Venturing, 14, 189-214.

Suryana. 2008. Kewirausahaan. Salemba empat. Jakarta. Fakultas Ekonomi Universitas Gajah Mada. Yogyakarta.

Sunarya, Sudaryono, Saefullah. (2011). Kewirausahaan. Yogyakarta: ANDI.

Slameto. 2003. Belajar dan Faktor-Faktor yang Mempengaruhinya. Jakarta : Rineka Cipta

Setiadi, U. (2008). Suatu Pemikiran Mengenai Pendekatan Kembali Antara Dunia Pendidikan S1 Manajemen Dengan Dunia Kerja.Prosiding Konferensi Merefleksi Domain Pendidikan Ekonomi dan Bisnis.Salatiga.

Sevilla, Consuelo G. et. all.(2007). Research Methods. Rex Printing Company. Quezon City. Pp. 182

Sholihin. Mahfud dan Dwi Ratmono.(2013). Analisis SEM-PLS dengan Warp PLS 3.0; untuk Hubungan Nonlinier dalam Penelitian Sosial dan Bisnis.Yogyakarta : CV Andi Offset 